\author{
В. В. Трач ${ }^{1}$ В. В. Данчук \\ ПОДІЛЬСЬКИЙ ДЕРЖАВНИЙ АГРАРНО-ТЕХНІЧНИЙ УНІВЕРСИТЕТ ${ }^{1}$ \\ КАМ'ЯНЕЦЬ-ПОДІЛЬСЬКИЙ \\ НАЦІОНАЛЬНИЙ УНІВЕРСИТЕТ БІОРЕСУРСІВ І ПРИРОДОКОРИСТУВАННЯ УКРАЇНИ, КИЇВ
}

\title{
АКТИВНІСТЬ СУПЕРОКСИДДИСМУТАЗИ У ТКАНИНАХ ПЕЧІНКИ ПЕРЕПЕЛІВ ПРИ ХІМІЧНІЙ ОБРОБЦІ ІНКУБАЦІЙНИХ ЯЄЦЬ ТА РІЗНОМУ РІВНI ВІТАМІНУ Е В РАЦІОНІ
}

Вступ. Стан антиоксидантної системи у тварин і птахів впливає на їх ріст, резистентність, продуктивність та якість продукції. Біологічна активність вітаміну Е зумовлена насамперед його антиоксидантною фрункцією. $\alpha$-токофрерол є найактивнішим природним антиоксидантом. Очевидно, застосування природних антиоксидантів дозволить підвищити активність системи антиоксидантного захисту.

Мета дослідження - визначити вплив хімічної обробки інкубаційних яєць та різного рівня вітаміну $E$ в раціоні маточного поголів'я на активність супероксиддисмутази в тканинах печінки перепелів.

Методи дослідження. Експерименти виконано на перепелах породи фрараон (Coturnix japonica) м'ясного напряму продуктивності. На 14-ту добу інкубації яйця перепелів було поділено на 7 груп. Обробку яєць проводили на 14-ту добу інкубації розчинами 1 \% натрію гіпохлориту, 2 \% хлоридної кислоти, 0,5 \% гідроген пероксиду. Матеріалом для досліджень слугували тканини печінки 14-добових ембріонів, 1- $і$ 10-добових перепелів. У гомогенаті тканин печінки визначали активність супероксиддисмутази (СОД).

Результати й обговорення. До 1-добового віку перепелів активність супероксиддисмутази збільшувалась, однак уже до 10-добового віку дещо зменшувалась (у межах 2,5%). Потрібно відмітити відсутність достовірної різниці в активності СОД у печінці 14-добових ембріонів перепелів усіх дослідних груп порівняно з контрольною. Хімічна обробка інкубаційних яєць супроводжувалась зниженням активності СОД у печінці перепелів порівняно з показником контрольної групи, хімічна їх обробка на 14-ту добу інкубації разом із додатковим введенням вітаміну Е до раціону маточного поголів'я - підвищенням активності СОД у печінці перепелів до 1-добового віку.

Висновки. При розвитку постнатального адаптаційного синдрому спостерігають збільшення активності системи антиоксидантного захисту в організмі перепелів. Зокрема, активність супероксиддисмутази в печінці 14-добових ембріонів перепелів до 1-добового віку птахів підвищується на 37,9 \% $(p<0,001)$. Додаткове введення вітаміну Е до раціону стимулює активність системи антиоксидантного захисту в печінці перепелів.

КЛЮчОВІ СЛОВА: перепели; ембріони; супероксиддисмутаза; печінка; вітамін Е.

ВСТУП. Застосування різних агресивних речовин для зняття кутикули провокує розвиток оксидативного стресу в ембріонів, що супроводжується модифікацією плазматичних мембран та зниженням активності ензимної ланки системи антиоксидантного захисту [1]. В тканинах ембріонів існує баланс між прооксидантною та антиоксидантною системами, який відіграє вирішальну роль у пренатальному і постнатальному розвитку птиці [2, 3]. Природні антиоксиданти взаємодіють один з одним для побудови антиоксидантної системи ембріона, який захищає від шкідливого впливу вільних радикалів і токсичного впливу продуктів пероксидного окиснення (c) В. В. Трач, В. В. Данчук, 2019. ліпідів [4]. Вітамін Е захищає ембріон під час розвитку від пероксидного окиснення ліпідів [5, 6]. Ензимна система антиоксидантного захисту $€$ основним фрактором захисту організму від дії активних фрорм Оксигену. Активність інших біохімічних систем, їх ефективність можуть відрізнятися залежно від стадії розвитку та фрізіології організму [7, 8]. Згідно з літературними даними, зниження або ж підвищення активності супероксиддисмутази (СОД) є причиною розвитку багатьох патологічних процесів [9]. Зниження рівня СОД відбувається внаслідок недостатнього захисту від активних фрорм кисню.

Мета дослідження - визначити вплив хімічної обробки інкубаційних яєць та різного рівня віта- 
міну Е в раціоні маточного поголів'я на активність супероксиддисмутази в тканинах печінки перепелів.

МЕТОДИ ДОСЛІДЖЕННЯ. Експериментальні дослідження проводили на перепелиній фрермі “ПП Забігалюк". Для досягнення поставленої мети було виконано дослід на 8-ми групах перепелів породи срараон (по 100 птахів у групі) відповідно до наведеної схеми (табл. 1).

Птахам контрольної групи згодовували стандартний комбікорм, збалансований за основними поживними та біологічно активними речовинами, відповідно до існуючих норм для перепелів ДСТУ 4687:2006. До стандартного комбікорму птахів дослідної групи додавали 20 г/т вітаміну Е. Після 4-х тижнів згодовування кормів відбирали інкубаційні яйця (1200 шт.). Оцінку інкубаційних якостей яєць проводили методами морфологічного та фрізико-хімічного контролю, для обліку ступеня ембріонального розвитку, аналізу результатів інкубації, встановлення віку та причини загибелі ембріонів застосовували методики біологічного контролю в інкубації, вірогідність отриманих результатів визначали методами варіаційної статистики.

Після передінкубаційного зберігання яєць перепелів, отриманих у пік несучості протягом 5-ти діб, їх зважували та закладали на інкубацію, застосовуючи стандартний режим. На 14-ту добу інкубації яйця перепелів було поділено на 7 груп (табл. 1). Обробку яєць проводили на 14-ту добу інкубації розчинами 1 \% натрію гіпохлориту, 2 \% хлоридної кислоти, 0,5 \% гідроген пероксиду. Матеріалом для досліджень слугували тканини печінки 14-добових ембріонів, 1- і 10-добових перепелів. У гомогенаті тканин печінки за методом С. Н. Чеварі та ін. визначали активність супероксиддисмутази (ЕС 1.15.1.1) [10].

РЕЗУЛЬТАТИЙ ОБГОВОРЕННЯ. АКТИВНіСТЬ основного ензиму системи антиоксидантного захисту - супероксиддисмутази в печінці 14-добових ембріонів перепелів контрольної групи до хімічної обробки інкубаційних яєць становила $(0,58 \pm 0,02)$ ум. од./г тканин. До 1-добового віку птахів її активність збільшилась на 37,9 \% ( $p<0,001)$, однак уже до 10-добового віку дещо зменшилась (у межах 2,5 \%) і складала
$(0,78 \pm 0,02)$ ум. од./г тканин (табл. 2). Потрібно відмітити відсутність достовірної різниці в активності СОД у печінці 14-добових ембріонів перепелів усіх дослідних груп порівняно з контрольною.

Хімічна обробка інкубаційних яєць супроводжувалась зниженням активності СОД у печінці перепелів порівняно з показником контрольної групи. Так, у птахів 1-ї дослідної групи з 14-ї доби ембріонального розвитку до 1-добового віку активність СОД збільшилась лише на 23,6 \% $(p<0,001)$ і стала на 15,0 \% ( $<<0,001)$ меншою, ніж у перепелів контрольної групи. 3 1-ї до 10-ї доби життя активність ензиму знизилась на 7,4 \% та залишалась на 19,2 \% ( $<<0,001)$ достовірно меншою від такої в перепелів контрольної групи.

Встановлено, що обробка інкубаційних яєць розчином гідроген пероксиду супроводжувалась зростанням активності СОД з 14-ї доби пренатального онтогенезу до 1-добового віку на 25,0 \% ( $<<0,001)$, внаслідок чого цей показник був меншим лише на 6,2 \% (тенденція) від значень перепелів контрольної групи. Надалі до 10-добового віку активність СОД у печінці птахів 2-ї дослідної групи знизилась на 5,3 \% і стала на $9 \%$ $(p<0,05)$ достовірно меншою від такої в перепелів контрольної групи.

Результати досліджень свідчать про те, що обробка інкубаційних яєць розчином натрію гіпохлориту супроводжувалась зростанням активності СОД у тканинах печінки з 14-ї доби інкубації до 1-добового віку перепелів на 26,3 \% (p<0,001). Так, у печінці 1-добових птахів 3-ї дослідної групи вона була на 10,0 \% (p<0,01) меншою від показника перепелів контрольної групи. 3 1-ї до 14-ї доби життя птахів активність СОД у їх печінці знизилась на 2,8 \% $(p<0,01)$ та залишалась на 10,3 \% меншою від такої в перепелів контрольної групи.

Додаткове введення вітаміну Е до раціону сприяло зростанню активності СОД у печінці перепелів. Так, у печінці 14-добових ембріонів птахів 4-7 дослідних груп вона становила 0,59-0,64 ум. од./г тканин, що на 2-10 \% більше від показника контрольної групи, зокрема, активність СОД у печінці 14-добових ембріонів перепелів 4-ї дослідної групи була на 6,9 \% вищою порівняно 3 контрольною групою. Надалі до 1-добового віку вона значно зростала (на 45,2 \%;

Таблиця 1 - Схема досліду

\begin{tabular}{|c|c|c|c|c|c|c|c|c|}
\hline \multirow[b]{2}{*}{$\begin{array}{l}\text { Умова } \\
\text { досліду }\end{array}$} & \multicolumn{8}{|c|}{ ГГрупа тварин } \\
\hline & контрольна & $\begin{array}{c}\text { 1-ша } \\
\text { дослідна }\end{array}$ & $\begin{array}{c}\text { 2-га } \\
\text { дослідна }\end{array}$ & $\begin{array}{c}\text { 3-тя } \\
\text { дослідна }\end{array}$ & $\begin{array}{c}\text { 4-та } \\
\text { дослідна }\end{array}$ & $\begin{array}{c}\text { 5-та } \\
\text { дослідна }\end{array}$ & $\begin{array}{c}\text { 6-та } \\
\text { дослідна }\end{array}$ & $\begin{array}{c}\text { 7-ма } \\
\text { дослідна }\end{array}$ \\
\hline Раціон & \multicolumn{4}{|c|}{ Стандартний комбікорм } & \multicolumn{4}{|c|}{$\begin{array}{l}\text { Стандартний комбікорм+20 мг/кг вітаміну E } \\
\text { (альфра-токофрерол DSM) }\end{array}$} \\
\hline Обробка яєць & - & $\mathrm{HCl}$ & $\mathrm{H}_{2} \mathrm{O}_{2}$ & $\mathrm{NaOCl}$ & - & $\mathrm{HCl}$ & $\mathrm{H}_{2} \mathrm{O}_{2}$ & $\mathrm{NaOCl}$ \\
\hline
\end{tabular}


$\mathrm{p}<0,001)$ і стала на $12,5 \%(\mathrm{p}<0,01)$ достовірно більшою, ніж у перепелів контрольної групи. 3 1- до 10-добового віку активність СОД у печінці птахів 4-ї дослідної групи зменшилась на 8,9 \% $(p<0,05)$ та достовірно не відрізнялась від такої в перепелів контрольної групи.

При хімічній обробці інкубаційних яєць розчином хлоридної кислоти та додатковому введенні вітаміну Е до раціону маточного поголів'я відзначали підвищення на 23,3 \% $(p<0,001)$ активності СОД у печінці 1-добових перепелів відповідно до показника 14-добових ембріонів. Активність цього ензиму в 1-добових перепелів була на 7,5-15,6 \% (p<0,05-0,001) достовірно меншою від такої в птахів контрольної та 4-ї дослідної груп і на 8,8 \% $(p<0,05)$ більшою від показника перепелів 1-ї дослідної групи. 3 1- до 10-добового віку активність СОД у печінці птахів 5-ї дослідної групи знизилась на 9,5 \% $(p<0,05)$ і стала на $14,1 \%(p<0,01)$ достовірно меншою від показника контрольної групи та на 18,3 \% $(p<0,01)$ - від показника перепелів 4-ї дослідної групи, однак на 6,3 \% вищою (в межах тенденції) від значення 1-ї дослідної групи.

Хімічна обробка інкубаційних яєць перепелів на 14-ту добу інкубації розчином гідроген пероксиду при додатковому введенні вітаміну Е до раціону маточного поголів'я (6-та дослідна група) супроводжувалась підвищенням на 28,8 \% $(p<0,001)$ активності СОД у печінці перепелів до 1-добового віку, яка достовірно не відрізнялась від показників птахів контрольної та 2-ї дослідної груп, однак була нижчою на 15,6 \% $(p<0,001)$ порівняно 3 4-ю дослідною групою. 3 1- до 10-добового віку активність ензиму в печінці перепелів 6-ї дослідної групи знизилась на 7,9 \% $(p<0,05)$ і стала на 14,6 \% $(p<0,01)$ достовірно більшою, ніж у птахів 2-ї дослідної групи, однак меншою на 10,3 \% (p<0,05) порівняно 3 контрольною групою.

Встановлено, що хімічна обробка інкубаційних яєць розчином натрію гіпохлориту при додатковому введенні вітаміну Е до раціону маточного поголів'я (6-та дослідна група) супроводжувалась підвищенням на 23,4 \% ( $<<0,001)$ активності СОД у печінці з 14-ї доби інкубації до 1-добового віку. Активність ензиму в печінці 1-добових перепелів стала на 9,7 \% $(p<0,051)$ більшою, ніж у птахів 3-ї дослідної групи, достовірно не відрізнялась від показника контрольної групи, однак була меншою на 15,6 \% $(p<0,01)$ від показника перепелів 4-ї дослідної групи. На наступному етапі досліджень 3 1- до 10-добового віку перепелів 7-ї дослідної групи активність СОД у їх печінці знизилась на 7,6 \% $(p<0,05)$ та достовірно не відрізнялась від такої в контрольній і 3-й дослідній групах, однак була на 11,0 \% $(p<0,01)$ меншою від показника птахів 4-ї дослідної групи.

Таким чином, визначено особливості активності супероксиддисмутази в тканинах печінки 14-добових ембріонів та 1 і 10-добових перепелів.

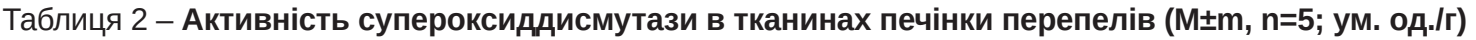

\begin{tabular}{|l|c|c|c|}
\hline \multicolumn{1}{|c|}{ Група перепелів } & \multicolumn{3}{|c|}{ Вік, доби } \\
\cline { 2 - 4 } & 14-добові ембріони & 1-добові перепели & 10-добові перепели \\
\hline Контрольна & $0,58 \pm 0,02$ & $0,80 \pm 0,01$ & $0,78 \pm 0,02$ \\
\hline 1-ша дослідна & $0,55 \pm 0,01$ & $0,68 \pm 0,02^{\star \star \star}$ & $0,63 \pm 0,02^{\star \star \star}$ \\
\hline 2-га дослідна & $0,60 \pm 0,02$ & $0,75 \pm 0,02$ & $0,71 \pm 0,02^{\star}$ \\
\hline 3-тя дослідна & $0,57 \pm 0,02$ & $0,72 \pm 0,02^{\star \star}$ & $0,70 \pm 0,01^{\star *}$ \\
\hline 4-та дослідна & $0,62 \pm 0,02$ & $0,90 \pm 0,03^{\star \star}$ & $0,82 \pm 0,01$ \\
\hline 5-та дослідна & $0,60 \pm 0,01$ & $0,74 \pm 0,02^{\star}$ & $0,67 \pm 0,01^{\star \star \star}$ \\
\hline 6-та дослідна & $0,59 \pm 0,02$ & $0,76 \pm 0,02$ & $0,70 \pm 0,03^{\star}$ \\
\hline 7-ма дослідна & $0,64 \pm 0,03$ & $0,79 \pm 0,05$ & $0,73 \pm 0,04$ \\
\hline \hline
\end{tabular}

Примітка. Різниця достовірна порівняно з контрольною групою $\left({ }^{*}-p<0,05 ;{ }^{* *}-p<0,01 ;{ }^{* *}-p<0,001\right)$.

ВИСНОВКИ. При розвитку постнатального адаптаційного синдрому спостерігають збільшення активності системи антиоксидантного захисту в організмі перепелів. Зокрема, активність супероксиддисмутази в печінці 14-добових ембріонів перепелів до 1-добового віку птахів підвищується на 37,9 \% (p<0,001). Додаткове введення вітаміну Е до раціону стимулює активність системи антиоксидантного захисту в печінці перепелів. 


\section{СПИСОК ЛІТЕРАТУРИ}

1. Трач В. В. Шляхи підвищення виводимості і життєздатності перепелів за умов хімічної обробки яєць в інкубаційний період / В. В. Трач, В.В.Данчук / Наук. вісн. НУБіП України. - 2017. - Вип. 265. C. 217-224.

2. Niki E. Dynamics of antioxidant action of vitamin E / E. Niki, N. Noguchi // Accounts of Chemical Research. 2004. - 37, No. 1. - P. 45-51.

3. Molecular mechanisms and new strategies to fight stresses in egg-producing birds / E. Shatskikh, E. Latypova, V. Fisinin [et al.] // Agricultural Science and Technology. - 2015. - 7, No. 1. - P. 3-10.

4. Surai P. F. Antioxidant systems in poultry biology: Nutritional modulation of vitagenes / P. F. Surai, I. I. Kochish, V. I. Fisinin // European Poultry Sciences. - 2017. 81.

5. Yigit A. A. The avian embryo and its antioxidant defence system / A. A. Yigit, A. K. Panda, G. Cherian // World's Poultry Science Journal. - 2014. - 70, No. 3. P. 563-574.

\section{REFERENCES}

1. Trach, V.V., \& Danchuk, V.V. (2018). Shliakhy pidvyshchennia vyvodymosti i zhyttiezdatnosti perepeliv za umov khimichnoi obrobky yaiets v inkubatsiinyi period [Ways to increase the hatchability and viability of quails under conditions of chemical treatment of eggs during the incubation period]. Ukrainskyi chasopys veterynarnykh nauk - Ukrainian Journal of Veterinary Sciences, (265), 217-224 [in Ukrainian].

2. Niki, E., \& Noguchi, N. (2004). Dynamics of antioxidant action of vitamin E. Accounts of Chemical Research, 37 (1), 45-51.

3. Shatskikh, E., Latypova, E., Fisinin, V., Denev, S., \& Surai, P. (2015). Molecular mechanisms and new strategies to fight stresses in egg-producing birds. Agricultural Science and Technology, 7 (1), 3-10.

4. Surai, P.F., Kochish, I.I., \& Fisinin, V.I. (2017). Antioxidant systems in poultry biology: Nutritional modulation of vitagenes. European Poultry Sciences, 81.

5. Yigit, A.A., Panda, A.K., \& Cherian, G. (2014). The avian embryo and its antioxidant defence system. World's Poultry Science Journal, 70 (3), 563-574.4.
6. Halliwell B. Free radicals in biology and medicine / B. Halliwell, J. M. Gutteridge. - Oxford University Press, USA, 2015.

7. Watson $\mathrm{H}$. Maternally derived yolk antioxidants buffer the developing avian embryo against oxidative stress induced by hyperoxia / H. Watson, P. Salmón, C. Isaksson // Journal of Experimental Biology. - 2018. 221, No. 13. - P. jeb179465.

8. Livingstone D. R. Contaminant-stimulated reactive oxygen species production and oxidative damage in aquatic organisms / D. R. Livingstone // Marine Pollution Bulletin. - 2001. - 42, No. 8. - P. 656-666.

9. Guan L. M. Cis-elements and trans-factors that regulate expression of the maize Cat1 antioxidant gene in response to ABA and osmotic stress: $\mathrm{H}_{2} \mathrm{O}_{2}$ is the likely intermediary signaling molecule for the response I L. M. Guan, J. Zhao, J. G. Scandalios // The Plant Journal. - 2000. - 22, No. 2. - P. 87-95.

10. Chevari S. Role of superoxide dismutase in cellular oxidative processes and method of its determination in biological materials // Lab. Delo. - 1985. 11. - P. 678-681.

6. Halliwell, B., \& Gutteridge, J.M. (2015). Free radicals in biology and medicine. Oxford University Press, USA.

7. Watson, H., Salmón, P., \& Isaksson, C. (2018). Maternally derived yolk antioxidants buffer the developing avian embryo against oxidative stress induced by hyperoxia. Journal of Experimental Biology, 221 (13), jeb179465.

8. Livingstone, D.R. (2001). Contaminant-stimulated reactive oxygen species production and oxidative damage in aquatic organisms. Marine Pollution Bulletin, 42 (8), 656-666.

9. Guan, L.M., Zhao, J., \& Scandalios, J.G. (2000). Cis-elements and trans-factors that regulate expression of the maize Cat1 antioxidant gene in response to ABA and osmotic stress: $\mathrm{H}_{2} \mathrm{O}_{2}$ is the likely intermediary signaling molecule for the response. The Plant Journal, 22 (2), 87-95.

10. Chevari, S. (1985). Role of superoxide dismutase in cellular oxidative processes and method of its determination in biological materials. Lab. Delo, 11, 678681. 


\section{В. В. Трач ${ }^{1}$ В. В. Данчук ${ }^{2}$ \\ ПОДОЛЬСКИЙ ГОСУДАРСТВЕННЫЙ АГРАРНО-ТЕХНИЧЕСКИЙ УНИВЕРСИТЕТ', КАМЕНЕЦ-ПОДОЛЬСКИЙ \\ НАЦИОНАЛЬНЫЙ УНИВЕРСИТЕТ БИОРЕСУРСОВ И ПРИРОДОПОЛЬЗОВАНИЯ УКРАИНЫ ${ }^{2}$, КИЕВ}

\section{АКТИВНОСТЬ СУПЕРОКСИДДИСМУТАЗЫ В ТКАНЯХ ПЕЧЕНИ ПЕРЕПЕЛОВ ПРИ ХИМИЧЕСКОЙ ОБРАБОТКЕ ИНКУБАЦИОННЫХ ЯИЦ И РАЗНОМ УРОВНЕ ВИТАМИНА Е В РАЦИОНЕ}

\section{Резюме}

Вступление. Состояние антиоксидантной системы у животных и птиц влияет на их рост, резистентность, производительность и качество продукции. Биологическая активность витамина $E$ обусловлена прежде всего его антиоксидантной фрункцией. $\alpha$-токоферол является самым активным природным антиоксидантом. Очевидно, применение природных антиоксидантов позволит повысить активность системы антиоксидантной защиты.

Цель исследования - определить влияние химической обработки инкубационных яиц и разного уровня витамина Е в рационе маточного поголовья на активность супероксиддисмутазы в тканях печени перепелов.

Методы исследования. Эксперименты выполнены на перепелах породы фрараон (Coturnix japonica) мясного направления продуктивности. На 14-е сутки инкубации яйца перепелов были расделены на 7 групп. Обработку яиц проводили на 14-е сутки инкубации растворами 1 \% натрия гипохлорита, 2 \% хлоридной кислоты, 0,5 \% водорода пероксида. Материалом для исследований служили ткани печени 14-суточных эмбрионов, 1- и 10-суточных перепелов. В гомогенате печени определяли активность супероксиддисмутазы (СОД).

Результаты и обсуждение. До 1-суточного возраста перепелов активность супероксиддисмутазы увеличивалась, однако уже к 10-суточному возрасту несколько уменьшалась (в пределах 2,5 \%). Нужно отметить отсутствие достоверной разницы в активности СОД в печени 14-суточных эмбрионов перепелов всех исследовательских групп по сравнению с контрольной. Химическая обработка инкубационных яиц сопровождалась снижением активности СОД в печени перепелов по сравнению с показателем контрольной группы, химическая их обработка на 14-е сутки инкубации вместе с дополнительным введением витамина Е в рацион маточного поголовья - повышением активности СОД в печени перепелов до 1-суточного возраста.

Выводы. При развитии постнатального адаптационного синдрома наблюдают увеличение активности системы антиоксидантной защиты в организме перепелов. В частности, активность супероксиддисмутазы в печени 14-суточных эмбрионов перепелов до 1-суточного возраста птиц повышается на 37,9 \% (p<0,001). Дополнительное введение витамина E в рацион стимулирует активность системы антиоксидантной защиты в печени перепелов.

КЛЮЧЕВЫЕ СЛОВА: перепела; эмбрионы; супероксиддисмутаза; печень; витамин Е.

V. V. $\operatorname{Trach}^{1}$, V. V. Danchuk ${ }^{2}$ PODILIA STATE AGRARIAN AND ENGINEERING UNIVERSITY' ${ }^{1}$, KAMIANETS-PODILSKYI NATIONAL UNIVERSITY OF BIORESOURCES AND NATURAL USE OF UKRAINE' ${ }^{2}$ KYIV

\section{SUPEROXIDE DISMUTASE ACTIVITY IN THE LIVER OF QUILTS DURING THE CHEMICAL PROCESSING OF HATCHING EGGS AND VARIOUS LEVEL OF VITAMIN E IN THE DIET}

\section{Summary}

Introduction. The state of the antioxidant system in animals and birds affects their growth, resistance, productivity and product quality. The biological activity of vitamin $E$ is due primarily to its antioxidant function. $\alpha$-tocopherol is an active natural antioxidant. Obviously, the use of natural antioxidants will increase the activity of the antioxidant defense system.

The aim of the study - to determine the effect of chemical treatment of hatching eggs and different levels of vitamin $E$ in the uterine population on the activity of superoxide dismutase in quail liver tissues.

Research Methods. The experiments were performed on quails of the pharaoh breed (Coturnix japonica) of the meat direction of productivity. On the $14^{\text {th }}$ day of incubation, quail eggs were divided into 7 groups. The eggs 
were treated on the 14th day of incubation with solutions of $1 \%$ sodium hypochlorite, $2 \%$ perchloric acid, $0.5 \%$ hydrogen peroxide. Liver tissue of 14-day-old embryos, 1- and 10-day-old quails served as a material for research. Superoxide dismutase (SOD) activity was determined in the liver homogenate.

Results and Discussion. Until the age of 1 day of quail, the activity of superoxide dismutase increases, however, already by the age of 10 days it slightly decreases (within $2.5 \%$ ). It should be noted the absence of significant differences in the activity of SOD in the liver of 14-day-old quail embryos of all research groups compared with the control group. The chemical treatment of the hatching eggs is accompanied by a decrease in the activity of SOD in the liver of quail as compared with the control group. The chemical treatment of quail hatching eggs on the $14^{\text {th }}$ day of incubation, together with the additional introduction of vitamin E into the diet of the uterine population, is accompanied by an increase in the activity of SOD in the quail liver up to 1 day old.

Conclusions. There is an increase in the activity of the antioxidant defense system in the quail organism during the development of postnatal adaptation syndrome. In particular, the activity of superoxide dismutase in the liver of 14-day-old quail embryos up to 1-day-old age increases. The additional introduction of vitamin $E$ into the diet stimulates the activity of the antioxidant defense system in the quail liver.

KEY WORDS: quail; embryo; superoxide dismutase; liver; vitamin E.

Отримано 15.08.19

Адреса для листування: В. В. Трач, Подільський державний аграрно-технічний університет, вул. Шевченка, 13, Кам'янецьПодільський, 32301, Україна, e-mail: trach-vv@ukr.net. 